\title{
Max Weber and the Great War: Personal Opinions and Essays as Historical Sociology*
}

\author{
Nikolay A. Golovin \\ Dr.Sci. (Sociology), Professor, Department of Theory and History of Sociology, \\ Saint Petersburg University \\ Address: Universitetskaya Emb., 7-9, Saint Petersburg, Russian Federation 199034 \\ E-mail: n.golovin@spbu.ru
}

\begin{abstract}
The influence of the Great War on the personality, sociology, political activity, and views of Max Weber has not yet been sufficiently researched. The second complete edition of works by Max Weber presents us with new opportunities to conduct a historical and sociological analysis of these issues. His personal letters and essays written during the Great War provide us with highly informative materials for such research. These materials, some of which are not widely known, are studied in the article from the perspective of historical sociology, whose co-founder was Weber himself. At the very beginning of the Great War, Max Weber underwent an emotional experience. He gave up lecturing for two years of army service in the hospital commission. After his service, he would make the shift to political speeches, declarations, and opinion essays. His previous understanding of the essence of war had been critically re-evaluated from the national and patriotic to the insight that Germany during and after the war would face a difficult choice between the trajectory of individual historical development and the Western path to political freedom. The article analyzes and sums up Weber's criticism of the politics of the German High Command which had obtained virtual governmental power in Germany. In particular, the article studies Weber's criticism of the total submarine warfare started by the German military in 1917-1918 and its political consequences. This political prevarication used by the commanders at the end of the Great War resulted in the tight connection between democracy and military defeat in German public opinion. Some of Weber's political forecasts are summed up and critically evaluated.
\end{abstract}

Keywords: Max Weber, history of sociology, historical sociology, sociology of war

Max Weber was actively involved in the politics of his age, an involvement which would have a great influence on his work. This fact became particularly evident during the Great War. Weber's political essays written during the war years are rather well known; their importance is not disputed, but the significance of wartime events for his scientific work is still insufficiently studied. Even rarer, newer publications lack clarity and consistency. It is important to keep in mind that Weber's circle of scientific communication narrowed sharply during the war. He was much more focused on his German scientific milieu, and considerably less so on the international one. German scientists were determined

(C) Nikolay A. Golovin, 2019

(C) Centre for Fundamental Sociology, 2019

DOI: $10.17323 / 1728-192 \mathrm{X}-2019-2-138-145$

* The article is prepared with the support of The Centre for German and European Studies, St. Petersburg State University — Bielefeld University, Grant 1/15/2019.

Статья подготовлена при поддержке ЦИГЕ СПбГУ и Университета Билефельда, грант от 15.01.2019. 
and belligerent. For example, Emil Lederer, a prominent economist, wrote in the Archiv für Sozialwissenschaft und Sozialpolitik, the famous journal co-edited by Weber, that the coming war would require a total effort to be exerted by all sides in a battle leading to their complete final exhaustion, for the loser and the winner alike (Lederer, 1915: 347384). We dare to admit that this view was shared by many German academics, including Weber himself. Weber, however, preserved his scientific principles along with the capacity for a sociological analysis of German politics, which, among other things, allowed him to make critical evaluations of the German High Command's strategy during the Great War. This combination of ardent political temperament and clear analytical mind is unique for the history of sociology. Hinnerk Bruhns, in his recent publication, suggests that the point can be "clarified by itself due to the various perspectives on the topic itself" (Bruhns, 2017: 201); however, no particular clarity "by itself" has been created for the readers.

\section{Weber's Criticism of the Military Politics of the German High Command}

The sudden outbreak of the Great War provoked the rise of patriotic sentiments. In August, 1914, the vast majority of warring European nations regarded the war to be defensive and just. Remembering the short-period military campaigns of 1866 and 1871, no one expected the war to be long or exhausting. The military of all ranks in the armies involved believed that the outcome of the war would be clear after several decisive battles at its beginning, and that they would all return home before the next Christmas.

The elite of European intellectuals, Henri Bergson, Anatole France, Sigmund Freud, Stefan George, Thomas Hardy, Thomas Mann, Marcel Proust, Rainer Maria Rilke, Herbert Wells, Ferdinand Tönnies, Werner Sombart, Émile Durkheim. and many others embraced the military euphoria. Weber often called the war "great and wonderful," and "a 'splendid' expenditure of heroic power and loving preparedness for sacrifice" (Weber, 1926: 530; Schneider, 1970: 90).

The war made him remarkably enthusiastic. Surprisingly, "he completely recovered" (Weber, 1926: 525) from the nervous illness that had been the reason for his leaving Heidelberg University for an indefinite period in the 1900 and refusing to participate in politics. He had been treated at health resorts, but the rehabilitation was slow-going. Weber continued to be involved in sociology, accepting the post of editor-in-chief of Archiv, and was in touch with his colleagues.

In the context of his above-mentioned reaction to the Great War, we should be reminded that the defensive military doctrine in Germany had been changed to the strategic offensive plan drawn up by Alfred von Schlieffen (1833-1913, Chief of the Imperial German General Staff in 1891-1905), or the so-called Schlieffen Plan devised in 19051906. The plan was to avoid the two-front war which primarily required a quick defeat of France in the West in combination with the German military forces' projection to the East with the consequent defeat of Russia (Pantenius, 2016). Considering the fact that the war was officially declared only on Russia, the implementation of the plan began in Bel- 
gium and France which were attacked without any declarations or claims. The European community was heavily impressed by this act of German aggressiveness. The war was known to have started in the Balkans, and France had nothing to do with that event. The Schlieffen Plan was already ruined in 1914 by the quick military mobilization in Russia, and the need for Germany to fight a two-front war.

The war continued, but military euphoria did not last for long. In Germany, societal disturbance and alarm were growing because of the unclear prospects of the war, and the destiny of the state. On March 11,1916, Weber told his wife that he "is atop of the volcano" (2008: 332). On September 4, 1916, in a letter to Bernhard Guttmann (1869-1959), a journalist and writer, he strategically defined further war development as follows: "If one of you, Gentlemen, ... asks: 'So, what are we supposed to fight for?' I'll answer: 'For our very existence as a nation with its own policy and self-orientation"' (Weber, 2008: 525). His situational analysis appeared to be historically correct.

The war seemed to be endless. Obviously, it was exhausting for the opponents. The war had changed the life-style of the Webers (along with other German citizens). It hurt his relatives and friends. The husband of his younger sister was killed in action at the Eastern theatre of war near Tannenberg in August, 1914. On August 22, 1915, his brother Karl was killed, as well as his friend, Emil Lask, in the same year (Weber, 1926: 537).

Since the beginning of war, the Reichstag proclaimed the "civil peace," and refused to control the German military by parliamentary methods as was done in the UK and France. In 1914, after the glorious victory of the battle of Tannenberg, the authority and influence of Oberste Heeresleitung (hereinafter referred as OHL, the High Military Command) had grown enormously. As the OHL's authority was so great because of the reinforcement by the high martial qualities of the Imperial German Army (Reichsheer), political power was moving gradually to the German Military. However, according to Bismarck's imperial constitution of Germany, the OHL was formally responsible to the Kaiser. The political power of the Kaiser became so limited that he withdrew into the shadows and preferred to follow the instructions of the OHL. Meanwhile, the continuing war aggravated the critical attitude towards the monarchy; the Kaiser was seen as responsible for the poverty, hunger, and the introduction of food rationing (Plenkov, 2011: 178-179). However, it did not mean that the OHL leaders were as good as longsighted professional politicians, according to Weber's own understanding of their important role.

Weber turned out to be one of the most authoritative critics of the OHL military poli$c y$, and his criticism was absolutely correct. Even his scrutiny of the four most important military and political decisions made by the OHL and the results of these decisions allows for an evaluation of the scientific depth and historical importance of Weber's analysis of historical alternatives. Among them were total submarine warfare, a separate peace with Russia, a fear that the transition from the imperial political institutions to democratic ones would be connected in public opinion with the hard and humiliating peace treaty conditions, and, finally, the issue of responsibility. for the war. The German military held that the sinking of British navy ships and civil vessels without any respect for the norms of international law would interrupt the British food and materiel supply lines would lift 
the naval blockade of Germany, and therefore would bring them victory within the second half of the year. (Naval surface attacks would have certainly been a losing proposition since the German navy was not comparable to the British navy's in terms of its fighting powers.)

Long before the beginning of total submarine warfare, Weber, along with outstanding political figures, contacted the Ministry of Foreign Affairs in March, 1916, with a memorandum called "Increasing U-boat warfare" (Die verschärfte U-Boot-Krieg) (Weber, 1984: 99-125). In this paper, he warned that war against civil vessels sailing to the UK with women and children on board would break the international law. Moreover, it would provoke the USA to join the war, which would be a disaster for Germany. Weber's address had its intended and far-reaching effect: the initiator of U-boat warfare, the German Grand Admiral von Tirpitz, was dismissed on March 15, 1916. Nevertheless, unrestricted submarine warfare started on February 1, 1917. German submarines ruined enemy vessels with a gross tonnage of 1 million tons, sixteen percent of which were British. The UK was on the brink of military defeat, but, as a result of the quick development of ASW (anti-submarine weapons), Germany suffered heavy losses which could not have been replenished in 1917 (in contrast to the Entente members with their superior resources). On April 6, 1917, as Weber had warned, the USA declared war on Germany in response to the total submarine warfare, and joined the Entente, making its economic and military potential even greater. Thus, Weber had not only predicted the defeat for Germany, but he also foresaw the rise of the United States whose financial support "would tie up the bankrupt European countries." Indeed, in the post-War period, the USA and the UK started to define the political governance in European countries, including Germany.

In his letters to the historian Hermann Oncken (1869-1945), Weber forecast that the Central European Empires (Germany and Austria-Hungary) "would be tied up to the American, financial system after the war, since we could not help them" (Weber, 2008: 842). Such a precise forecast about the changes of the world order and the composition of its political forces was constantly repeated by Weber. This fact proves the efficiency of his historical sociology. Thus, he connected American participation in the war across the Atlantic with the further rise of the United States as a superpower. Since 1915, the German High Command had been looking for a separate peace with Russia, although unsuccessfully. After the February 1917 Revolution in Russia, Weber considered a peace treaty with Russians to be a good option. He approved the statement released by the Russian Provisional Government on May 4, 1917 (April 17, OS), which proclaimed that "Russia along with its decisive victory will refrain from territory acquisition and extension of its power at the expense of other states" (Ibid.: 632). In a May 8, 1917, letter to the authoritative politician Friedrich Naumann, Weber advised his addressee to publicly announce that "we should immediately take the Russian position: no restitutions or reparations, granting of mutual guarantees eliminating warfare threats to the other party, a peace treaty conclusion," the refusal of claims against Western powers, irrespective of their "support ... of military goals inconsistent with the demands of the Russian government" (Ibid.: $632-633)$. 
In 1918, the German Military launched a total offensive in the Eastern theatre of the war. On March 3,1918, Soviet Russia was forced to sign the "extortionate" Brest-Litovsk Peace Treaty, losing 1 million square kilometers of their territory populated by 56 million people. Weber criticized the pressure exerted by the German Command on the Soviet delegation at the peace negotiations. He wrote to his wife that "present events in BrestLitovsk do not make good impressions" (Weber, 1989: 53).

Weber held that the Treaty of Brest-Litovsk would last only for the period of Russia's weakness. He turned out to be correct. On November 11, 1918, the new German revolutionary government withdrew from the Treaty, and on November 13, 1918, Soviet Russia cancelled it as well. Thus, the Treaty, despite the OHL's plans, gave Germany neither food nor any other resources to continue the war. The Allies got a sufficient impression of German's "extortionate" behavior, having been pointed out by Weber in his public speeches and private correspondence.

At the end of the Great War, Weber, being an experienced and responsible politician, noted that fear would arise as the transition from imperial political institutions to democratic ones would be linked in German public opinion with the difficult and humiliating peace treaty conditions formalizing Germany's military defeat. On July 15, 1917, he wrote to Otto Thomas, a leader of the labor movement: "It might have been unwise to heavily underline the link between domestic democratization and the peace treaty, given that this link exists and appears to be true ... Anyway, democracy is essential for national reasons and the Germans deserve it irrespective of peace" (Weber, 2008: 695-696). Obviously, Weber comprehended that democracy as dictated by the Allies could be perceived negatively by Germans. In this respect, he appeared to be a prophet; in the autumn of 1918, the OHL, hoping to save the army, agreed to a truce that avoided a military disaster. Then, the OHL performed the maneuver Weber had been warning about. On October 28, 1918, a few days before the Empire's end, at the Command's insistence, the government was made accountable to Parliament, and a new government was formed. In doing so, Germany made the transition to the Western political system, since the Chancellor became responsible to the Reichstag and not to the Kaiser.

A skillful maneuver of the military was to shift the responsibility for the defeat upon the democratic government and the Parliament who sanctioned the signing of a severe peace treaty. General Erich Ludendorff, the Chief of the General Staff would say: "Gentlemen, Social Democrats have to conclude a peace treaty which must be signed right now. They have to put the mess right. The mess they had created for us!" The maneuver was rather successful: in German public opinion, democracy and the military defeat have become synonyms for decades. Soon the Nazis would make huge political capital out of the struggle with democracy, destroying it and bringing German history to a deadlock. Here, Weber turned out to be a true political forecaster.

Weber held that blaming Germany for the outbreak of war was unbearably unfair, and this thought completely coincided with German public opinion. He studied the findings of the Allies on this issue and came to a conclusion about Russia's fault in the outbreak of war, pointing out its geopolitical interests in the Balkans and the Turkish Straits (Weber, 
1984: 343). The said ambitions in relation to the Dardanelles and Bosphorus (also known as Bosporus) actually existed in Russian society, although these ambitions turned out to be unsound and unrealizable.

Along with other German politicians and journalists, Weber started an active struggle against the idea of blaming Germany for the war. On February 3 or 4 in 1919, he and his colleagues founded the "The Heidelberger Society for Legal Policy" (Arbeitsgemeinschaft für Politik des Rechts, Heidelberger Vereinigung). He presented a worked-out "united" position of the Society during the Versailles negotiations held from May 15-28, 1919. He violently opposed the ratification of the Treaty of Versailles with its enormously tough and humiliating conditions for Germany. In fact, the reparation sums were so huge that the country stopped paying interest on them, taking into account all further financial settlements. It would only be in 2010, ninety-two years after the war ended, that the debt would be settled, having been paid by the work of three post-war generations. All of this could hardly be called a fair deal. The issue of responsibility for the Great War is a problem even today. Historians have failed to identify a unified reason for this. A majority of modern experts held that it was exactly this issue that led to the outbreak of WWII (Plenkov, 2014: 176). Despite the fact that these results have been obtained by the efforts of several generations of historians, Weber, who has pointed out the unfairness of the Versailles Treaty, was the first among its shrewdest critics.

Weber's criticism of the German High Command's politics, including total submarine warfare, the pressure excised on Russia to conclude the Treaty of Brest-Litovsk, the predatory annexations, and war indemnities turned out to be historically true. He precisely evaluated the outcomes of these politics for Germany and for the world. As one of only a few, he managed to foresee the OHL's anti-democratic maneuvers linking democracy and the humiliating Treaty of Versailles in German public opinion. His understanding of the hopeless, exhausting war for Germany was much deeper than the OHL's strategic plans which aimed to crush one enemy after another at any cost, according to the thoughts of Field Marshal Schlieffen. It is not really necessary to be a sophisticated military strategist to have a deep understanding of the reality of war in the 2oth century. It was enough to be a sociologist sensible to the reality of a new mass society which declared itself with the beginning of the World War.

\section{Concluding Remarks}

To conclude, the main case of this article is to prove the point that Weber's choice in favor of writing political essays during the Great War is only at first glance the decision applicable to his own dilemma of science versus politics. As the analysis has shown, Weber's essays and public speeches addressed to the German public and his signing of collective appeals are all correlative with thoughts from his letters, and could not be derived from his historical sociology as it is. Weber's sociology and political essays set out and solved some methodological and historical questions on the public choice between the historical alternatives of further development. They give certain answers that explain why and how 
did the world of modern politics find itself in this particular situation. If we only take into account the present research perspective of historical sociology, there is a possibility to explain the objectiveness and independence of Weber's evaluations given to the military and historical reality, and contrast them with other opinions and assessments that exist in the academic world and with the unavoidable German High Command propaganda. Our significant conclusion is that, on one hand, we should agree with a well-known evaluation given by the historian W. Mommsen (1930-2004) that "in his [Weber's] political system of values the main roles were given to the nation, power and culture" (Mommsen, 1974: 90-96, 132-133). Weber's value system, as it can be traced from our analysis, was dominated by those scientific values where conclusiveness always overpowers any other value, including national ideas or political passions. Thus, the objective character of his values is explained and, moreover, proven by the very history of modernity.

The present research of Weber's active engagement in the events of the Great War shows that his political essays and public speeches represent not only his participation in politics through their method, analytical depth, and historical authenticity of their results, but also demonstrates an essential contribution to applied historical sociology.

\section{References}

Bruhns H. (2017) Max Weber und der Erste Weltkrieg, Tübingen: J.C.B. Mohr (Paul Siebeck).

Lederer E. (1915) Zur Soziologie des Weltkrieges. Archiv für Sozialwissenschaft und Sozialpolitik, vol. 39, no 3, pp. 347-384.

Mommsen W. (1974) Max Weber und die deutsche Politik, 189o-1920, Tübingen: J. C. B. Mohr (Paul Siebeck).

Pantenius W. H. (ed.) (2016) Alfred Grafvon Schliffen: Stratege zwischen Befreiungskriegen und Stahlgewittern, Leipzig: Eudora.

Plenkov O. (2011) Triumf mifa nad razumom [Triumph of the Myth over the Mind], Saint Petersburg: Vladimir Dal.

Plenkov O. (2014) Istoki sovremennosti: dinamika i logika razvitiia Zapada v Noveishee vremia [The Origins of Modernity: Dynamics and Logic of the Development of the West in the Present Time], Saint Petersburg: Voskhod.

Schneider L. (1970) Sociological Approach to Religion, New York: Wiley.

Thaer A. (2018) Erich Ludendorff gesteht die Niederlage ein: aus den Tagebuchnotizen von Albrecht von Thaer (1.10.1918). Available at: http://germanhistorydcs.ghi-dc.org/ sub_document.cfm?document_id=814\&language=german (accessed 19 June 2019).

Weber M. (1926) Max Weber: Ein Lebensbild, Tübingen: J. C. B. Mohr (Paul Siebeck).

Weber M. (1984) Max-Weber-Gesamtausgabe, Vol. I/15: Zur Politik im Weltkrieg: Schriften und Reden 1914-1918, Tübingen: J. C. B. Mohr (Paul Siebeck).

Weber M. (1988) Max-Weber-Gesamtausgabe, Vol. I/16: Zur Neuordnung Deutschlands: Schriften und Reden 1918-1920, Tübingen: J. C. B. Mohr (Paul Siebeck).

Weber M. (2008) Max-Weber-Gesamtausgabe. Vol. II/9: Briefe 1915-1917, Tübingen: J. C. B. Mohr (Paul Siebeck). 


\title{
Макс Вебер и Великая война: личное мнение и публицистика как историческая социология
}

\author{
Николай Головин \\ Доктор социологических наук, профессор кафедры теории и истории социологии \\ Санкт-Петербургского государственного университета \\ Адрес: Университетская набережная, д. 7-9, Санкт-Петербург, Россия 199034 \\ E-mail:n.golovin@spbu.ru
}

Влияние Первой мировой войны на личность, социологию, политическую деятельность и взгляды Макса Вебера изучено недостаточно. Завершающееся издание полного собрания его сочинений, содержащее личную переписку и публицистику военных лет, открывает новые возможности исследования названных вопросов. Некоторые из этих материалов, в том числе малоизвестные, исследуются в данной статье в аспекте веберовской исторической социологии. В начале Великой войны он пережил эмоциональный подъем и в 5о-летем возрасте добился назначения военным членом лазаретной комиссии, на два года оставив почти все иные занятия. По мере затягивания войны он включился в политику в качестве публициста и общественного деятеля. В ходе войны его национальнопатриотическая позиция эволюционировала от вопроса о месте Германии среди мировых держав к внутриполитическим вопросам, прежде всего необходимости скорейшего перехода к политической системе западного типа. В статье доказано, что в годы Великой войны Вебер лишь на первый взгляд сменил науку на политику в силу исторических обстоятельств. Обращения Вебера-публициста к общегерманской аудитории, его публичные выступления, подписание коллективных воззваний, его личная переписка, проникнуты теоретическими положениями его исторической социологии.

Ключевые слова: Макс Вебер, история социологии, историческая социология, социология войны 